\title{
Provision of contrasted nitrogen-related ecosystem services among grain legumes
}

\author{
Maé Guinet $^{1}(\mathbb{D}) \cdot$ Bernard Nicolardot $^{1} \cdot$ Anne-Sophie Voisin $^{1}$
}

Accepted: 3 August 2020 / Published online: 24 August 2020

(C) INRAE and Springer-Verlag France SAS, part of Springer Nature 2020

\begin{abstract}
Legumes deliver unique functions that are complementary to those of other groups of species (cereals and oil-rich crops), providing many ecosystem services related to nitrogen. However, the choice of grain legumes according to their ability to provide these ecosystem services remains difficult due to a lack of references for a variety of species. During two legume wheat successions established between 2014 and 2017, five nitrogen pools were measured, and considered as proxies of nitrogen functions supporting ecosystem services and dis-services. Nitrogen pools were analyzed together with several of their explanatory shoot and root characteristics (i.e. plant traits and properties). For the first time, a wide range of grain legumes could be characterized by their contrasted functional profiles relative to nitrogen. For each species, synergies and trade-offs between the different nitrogen functions were highlighted and related to the explanatory plant characteristics. Shoot and root characteristics explained $76.1 \%$ of the variability of nitrogen functions among legumes species. Chickpea, common bean, and soybean had high capacity to take up soil nitrogen during their growth cycles, reducing the risk of nitrogen losses after their harvest. These species were characterized by a high root lateral expansion rate and their capacity to invest a large proportion of belowground biomass in nodules. Conversely, common vetch, faba bean, lentil, pea and Narbonne vetch, were less able to take up soil nitrogen, with higher risks of nitrogen losses, but these species induced high amounts of nitrogen in the following wheat crop and were characterized by high crop residue nitrogen concentration. Larger amounts of nitrogen fixed and exported in seeds were measured for species characterized by high shoot dry matter, high nitrogen harvest index, high seed nitrogen concentration, and large seeds. Hence, this study should facilitate the selection of legume species according to the expected objectives.
\end{abstract}

Keywords Functional profile $\cdot$ Plant traits $\cdot$ Multifunctionality index $\cdot$ Symbiotic nitrogen fixation $\cdot$ Seed nitrogen $\cdot$ Iorganic nitrogen uptake $\cdot$ Nitrogen leaching $\cdot$ Pre-crop nitrogen benefits

\section{Introduction}

To overcome environmental issues (water soil and air pollution, biodiversity loss, etc.) and resource scarcity in the context of climate change, cropping systems must enable the production of agricultural goods through a better resource use efficiency while minimizing negative impacts on the environments (Tilman et al. 2002).

In the context of agroecological transition, ecosystem services should be maximized to ensure agricultural production

Anne-Sophie Voisin

anne-sophie.voisin@inrae.fr

1 UMR Agroécologie, AgroSup Dijon, INRAE, University of Bourgogne, University of Bourgogne Franche Comté, F-21000 Dijon, France while reducing farm inputs (MEA 2005; Power 2010; Tibi and Therond 2017). The provision of ecosystem services relies in particular on the reintroduction of spatial and temporal biodiversity (Isbell et al. 2011) in farming landscapes and in cropping fields. Indeed, species diversity in agricultural ecosystem ensures a variety of ecological functions, resulting from ecological processes, and providing ecosystem services. Synergy between ecological functions induced by different species allows: i) more efficient resource use, ii) the simultaneous provision of a wider range of ecosystem services, and iii) better adaptation to environmental disruptions.

Although legumes deliver unique and complementary ecological functions to those of other groups of species (Peoples et al. 2019) grain and forage legumes only represent $3 \%$ of the French agricultural land (Voisin et al. 2014). Consequently, legumes should play a leading role in the provision of ecosystem services relative to nitrogen $(\mathrm{N})$ when reintroduced in 
cropping systems that are mainly based on cereals and oleaginous species. Legumes deliver provisioning services through the production of protein-rich seeds and forages. Legumes also support $\mathrm{N}$ supply to crops, thanks to their unique ability to establish a symbiosis with specific soil rhizobia bacteria that are able to fix atmospheric $\mathrm{N}_{2}$, thus providing $\mathrm{N}$ to the plant (Guinet et al. 2018). Moreover, legumes supply $\mathrm{N}$ to the following crops of the succession, through the mineralization of their N-rich crop residues (Peoples et al. 2019). However, the introduction of legumes in cropping systems can result in some dis-services, due to soil $\mathrm{N}$ losses in the environment by leaching and gas emissions during their growth cycle and after their harvest (Peoples et al. 2019; Plaza-Bonilla et al. 2015). Indeed, more $\mathrm{N}$ is left in the soil after legume harvest, due to their lower ability to take up soil $\mathrm{N}$ compared to cereals (Hauggaard-Nielsen et al. 2001). Moreover, the desynchronization between $\mathrm{N}$ supply to the soil by legume residue mineralization and the $\mathrm{N}$ demand of the following crop, can lead to soil $\mathrm{N}$ losses during the fallow period. Such soil $\mathrm{N}$ losses are highly dependent on i) rainfall amount and distribution during these periods, ii) soil water holding capacity and iii) soil microbial activity (Peoples et al. 2019).

While ecosystem services delivered by legumes have been widely studied, especially in comparison to cereals (Peoples et al. 2019), little is known about the differences that may exist among a wide range of legume species. Given the large diversity of grain legumes, it is important to characterize and distinguish them based on their ability to deliver ecological functions that provide ecosystem services relative to N. Hence, it would facilitate the selection of grain legumes according to the objectives desired (Damour et al. 2014) and carry out appropriate management of $\mathrm{N}$ resources in cropping systems that include legumes. Synergies and trade-offs between the different ecological $\mathrm{N}$ functions delivered by legumes must be identified to determine the ability of different species to simultaneously provide multiple ecosystem services while limiting dis-services (Bennett et al. 2009; Lescourret et al. 2015).

Nitrogen functions occurring during and after legume growth can be approximated by $\mathrm{N}$ pools resulting from $\mathrm{N}$ processes integrated over a given period of time. However, the systematic measurement of $\mathrm{N}$ pools under a wide range of environmental conditions and diversity of species is costly and time consuming. To overcome these constraints, species can be characterized by traits that determine the effect of plants on ecological functions (Garnier and Navas 2012). Plant traits are commonly defined as "any morphological, physiological or phenological feature measurable at the individual level from the cell to the whole-organism level, without reference to the environment or any other level of organization" (Violle et al. 2007). Based on this approach, species can be characterized and classified as a function of a combination of similar trait attributes (i.e. the specific value of each trait in a given environment and at a given time), which can be considered as predictors of the ecological functions and the resulting ecosystem services or dis-services.

Based on the framework of trait - ecological function ecosystem services, our objective was to characterize and distinguish ten grain legume species according to their provision of ecosystem services or dis-services relative to N (Fig. 1). A three-step approach was carried out to: i) quantify a set of five $\mathrm{N}$ functions (approximated by $\mathrm{N}$ pools) delivered by legumes and providing a series of ecosystem services or dis-services; they were measured over a two-year legume - cereal succession, ii) identify and measure explanatory plant characteristics of the different $\mathrm{N}$ functions, and iii) establish the functional profile of these ten legume species in order to determine their ability to deliver several simultaneous ecosystem services relative to $\mathrm{N}$.

\section{Materials and methods}

\subsection{Conceptual framework}

This study was based on a framework of trait - ecological function - ecosystem services, using well established concepts applied to study agro-ecosystems (Lescourret et al. 2015; Tibi and Therond 2017). Agro-ecosystems can be characterized by their structural and functional components. The structural components include the physical, geochemical (here rainfall, temperature and soil characteristics) and the biological (here legume species identity) compartments. The functional components of agro-ecosystems are the biophysical and biological processes occurring in the ecosystem (here $\mathrm{N}$-cycling processes, i.e. transformation of one form of $\mathrm{N}$ into another) occurring in the soil - plant - air continuum during and after legume growth. Legume characteristics that are assumed to influence the intensity of $\mathrm{N}$ processes were measured either at the plant level (referred as plant traits; Violle et al. 2007) or at the population level (referred as plant properties; Damour et al. 2014).

Ecological functions are the result of close interactions between natural processes (here $\mathrm{N}$ processes) and structural components (here legumes) that support ecosystem services. In this study, ecological $\mathrm{N}$ functions, delivered by legumes, were approximated by $\mathrm{N}$ pools resulting from $\mathrm{N}$ processes integrated over specific periods of time in a two-year legume - cereal succession (e.g. the amount of $\mathrm{N}$ fixed over the legume growth cycle, measured in legume shoots at plant physiological maturity). The resulting ecosystem services were classified in four categories as suggested by the MEA (2005): provisioning, regulating, cultural and supporting services. The first three categories directly affect human wellbeing, while the fourth category maintains the other three. We also considered dis-services, defined as the negative impacts for humans, resulting from ecosystem functioning. 


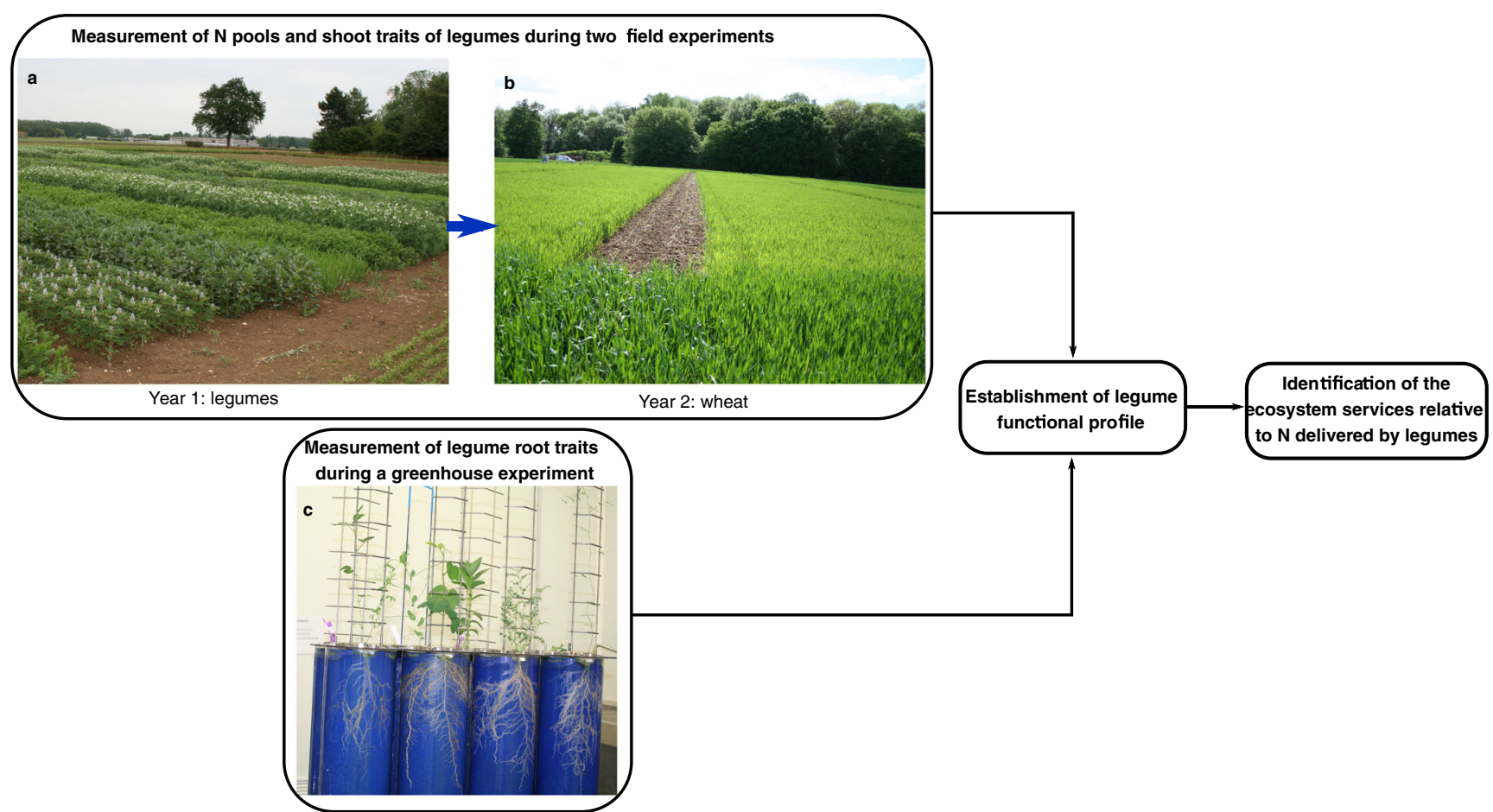

Fig. 1 Conceptual framework diagram. a Plots of grain legumes at flowering showing the diversity of shoot characteristics. From left to right: lupin, lentil, common vetch, lupin, fababean, common vetch, pea

\subsection{Experimental set up}

\subsubsection{Field experiments}

Two field experiments, each lasting two years, were carried at the INRAE experimental site of Bretenière (Dijon, France, $47.241 \mathrm{~N}, 5.115 \mathrm{E}, 206 \mathrm{~m}$ a.s.1.) in 2014-2015 (Experiment I) and 2016-2017 (Experiment II) in two neighboring fields with very similar soil characteristics. The soil is a Cambisol with a clay surface layer (depth $0.65 \pm 0.15 \mathrm{~m}$ ) developed on an alluvial coarse layer. Soil characteristics are: clay $=469 \mathrm{~g} \mathrm{~kg}^{-1}$, silt $=471 \mathrm{~g} \mathrm{~kg}^{-1}$, sand $=60 \mathrm{~g} \mathrm{~kg}^{-1}$, organic $\mathrm{C}=19.3 \mathrm{~g} \mathrm{~kg}^{-1}$, organic $\mathrm{N}=$ $1.75 \mathrm{~g} \mathrm{~kg}^{-1}, \mathrm{pH}=7.5, \mathrm{CaCO}_{3}<1 \mathrm{~g} \mathrm{~kg}^{-1}$. The site is subject to a semi-continental climate characterized by cold winters (average daily temperature of $3^{\circ} \mathrm{C}$ and average monthly rainfall of $44 \mathrm{~mm}$ ) and hot summers (average daily temperature of $19^{\circ} \mathrm{C}$ and average monthly rainfall of $73 \mathrm{~mm}$ ). The first years of each experiment (2014 and 2016) were characterized by contrasted rainfall distribution during the year. Between March and June, rainfall was unusually low in 2014 (102 $\mathrm{mm}$ ) and unusually high in 2016 (399 mm), compared to the mean rainfall over the last 20 years during the same period $(255 \mathrm{~mm})$. In contrast, between July and November, rainfall was unusually high in 2014 (541 mm) compared to 2016 (303 $\mathrm{mm}$ ) and to the mean rainfall over the last 20 years during the same period $(362 \mathrm{~mm})$.
(ㄷ) Marlène LEFEBVRE, May 2014). b Plots of wheat following legume pre-crops (@ Marlène LEFEBVRE, May 2015). c Roots of legumes cultivated in rhizotrons (@ Maé GUINET, February 2016)

During the first year (2014 and 2016), nine grain legumes were sown either in March (Vicia sativa L., 1753: common vetch, Vicia faba L., 1753: faba bean, Lens culinaris (L.) Coss \& Germ., 1845 subsp. lens: lentil, Lupinus albus L., 1753: lupin and Pisium sativum L., 1753: pea) or in May (Cicer arietinum L., 1753: chickpea, Phaseolus vulgaris L., 1753: common bean, Vicia narbonensis L., 1753: Narbonne vetch, and Glycine $\max$ (L.) Merr., 1917: soybean), based on the physiological requirements of each species. In 2016, fenugreek (Trigonalla foenum-gracum L., 1753) was also sown in March. One cultivar per species was chosen as it was the most cultivated cultivar in France and/or the most adapted to the climatic conditions in Burgundy (Table 1). At sowing, inorganic $\mathrm{N}$ contents in the upper $60 \mathrm{~cm}$ of the soil were $69 \mathrm{~kg} \mathrm{~N} \mathrm{ha}^{-1}$ in March 2014, $84 \mathrm{~kg} \mathrm{~N} \mathrm{ha}^{-1}$ in May 2014, $94 \mathrm{~kg} \mathrm{~N} \mathrm{ha}^{-1}$ in March 2016 and $115 \mathrm{~kg} \mathrm{~N}^{-1}$ in May 2016. Seeds of the ten legumes were inoculated upon sowing, with species-specific strains of $\mathrm{N}_{2}$-fixing bacteria, with at least $10^{5}$ and $10^{6}$ viable rhizobia per seed, for small and large seeded legumes, respectively. The liquid inoculant was mixed with adhesive carrier (contained in the FORCE 48 packaging, BASF) to ensure the inoculant stuck to the seeds. The rhizobia strains were known or previously tested in the greenhouse to ensure symbiotic $\mathrm{N}_{2}$ fixation (Table 1). These strains were obtained from the "Agro-environmental microorganisms of interest" collection maintained at UMR Agroecologie, INRAE, Dijon. Further information on the 
Table 1 Cultivar, sowing density, row spacing and Rhizobium strain, for the ten legume crops and two cereals

\begin{tabular}{lllll}
\hline Pre-crop species & Cultivar & $\begin{array}{l}\text { Sowing density } \\
\left(\text { seeds }{ }^{-2}\right)\end{array}$ & Row spacing (cm) & Rhizobium strain \\
\hline Common vetch & Candy & 100 & 20 & Rhizobium leguminosarum bv. Viciae MIAE01212 (MSDJ469, P221) \\
Faba bean & Espresso & 45 & 25 & Rhizobium leguminosarum bv. Viciae MIAE01211 (MSDJ822, FH34) \\
Fenugreek & Fenu-fix & 180 & 16 & Ensifer sp. (Trigonella) MIAE06333 (MSDJ3531) \\
Lentil & Anicia & 250 & 20 & Rhizobium leguminosarum bv. Viciae MIAE01212 (MSDJ469, P221) \\
Lupin & Feodora & 70 & 25 & Bradyrhizobium sp. (Lupinus) MIAE00428 (MSDJ718, LL13) \\
Pea & Kayanne & 80 & 25 & Rhizobium leguminosarum bv. Viciae MIAE01212 (MSDJ469, P221) \\
Barley & Irina & 350 & 15 & none \\
Chickpea & Twist / Vulcano & $70 / 55$ & $20 / 20$ & Mesorhizobium sp. (Cicer) MIAE04996 (MSDJ2193, 3HOa8) \\
Common bean & Flavert & 30 & 25 & Rhizobium etli MIAE05216 (MSDJ2414, GD164) \\
Narbonne vetch & Clara & 35 & 20 & Rhizobium leguminosarum bv. Viciae MIAE01212 (MSDJ469, P221) \\
Soybean & Sultana (000) & 70 & 25 & Bradyrhizobium diazoefficiens MIAE00426 (MSDJ1996, G49) \\
Sorghum & Québec & 30 & 35 & none \\
\hline
\end{tabular}

references of the rhizobia strains can be found in Guinet et al. (2018).

To estimate symbiotic $\mathrm{N}_{2}$ fixation, the ${ }^{15} \mathrm{~N}$ isotope dilution method was used with unfertilized $\mathrm{N}$ cereals as reference nonfixing crops: barley (Hordeum vulgare L., 1753; for legumes sown in March) and sorghum (Sorghum bicolor (L.) Moench, 1794; for legumes sown in May). To this end, $5 \mathrm{~kg} \mathrm{~N}^{-1}$ of $\mathrm{NH}_{4} \mathrm{NO}_{3}$ labeled with $1 \%{ }^{15} \mathrm{~N}$ was dissolved in water and spread on the soil at a rate of $300 \mathrm{~L} \mathrm{ha}^{-1}$ at legumes and cereals sowing. Considering the very small amount of $\mathrm{N}$ applied, this treatment is hereafter referred to as the unfertilized treatment. An additional $\mathrm{N}$ treatment was applied to both cereals (barley and sorghum) to compare the $\mathrm{N}$ functions delivered by $\mathrm{N}$ fertilized cereals with those delivered by legumes. Nitrogen fertilization was applied as solid $\mathrm{NH}_{4} \mathrm{NO}_{3}$ at rates of 60 and $75 \mathrm{~kg} \mathrm{~N} \mathrm{ha}^{-1}$ in 2014 (3rd and 28th April, respectively) for barley. In 2016, due to the extremely wet conditions in April and May, only $70 \mathrm{~kg} \mathrm{~N} \mathrm{ha}^{-1}$ were applied on barley on the 19 th of April to reduce the risk of $\mathrm{N}$ leaching. $\mathrm{N}$ fertilizer was applied twice during sorghum growth at rates of $50 \mathrm{~kg} \mathrm{~N}$ $\mathrm{ha}^{-1}$ each in 2014 (9th May and 13th June) and 2016 (7th June and 7th July). Legumes and cereals were cultivated on $1.5 \mathrm{~m}$ wide and $12 \mathrm{~m}$ long plots with four replicates for each species and $\mathrm{N}$ fertilization rates for cereals (i.e. 4 replicates for each $\mathrm{N}$ fertilized and unfertilized cereals) in a fully randomized design. Each plot was surrounded by a $25 \mathrm{~cm}$ alley to limit inter-plot hedge effect. Sowing density and row spacing of each crop can be found in Table 1 .

After harvesting the seeds of legumes and N-fertilized cereals, residues were chopped and incorporated into the soil. No seeds were harvested for Narbonne vetch in 2014 and 2016 and for chickpea in 2016, due to climatic conditions that were unsuitable for seed production for these two species. In these cases, whole plants were considered as shoot residues and are referred to as 'cover-crops'(cc) hereafter. Winter wheat (Triticum aestivum L., 1753; cv. Rubisko; 350 seeds $\mathrm{m}^{-2} ; 16 \mathrm{~cm}$ row spacing) was sown in October as a following crop for each of the legume and $\mathrm{N}$ fertilized cereal pre-crops, and was not supplied with $\mathrm{N}$ fertilizer. Wheat was then harvested in July 2015 and 2017, respectively.

\subsubsection{Greenhouse experiment}

A greenhouse experiment was carried out in 2016 at the Plant Phenotyping Platform for Plant and Microorganism Interaction (4PMI) at INRAE Dijon (France) to measure root traits of the same ten grain legumes, using the same rhizobia strains as in the field experiments. Legumes (4 replicates per species) were cultivated in cylindrical RhizoTubes $@$, measuring $49.5 \mathrm{~cm}$ high and $18 \mathrm{~cm}$ diameter, in which roots were confined in a two-dimension zone between an inner permeable membrane and an outer transparent tube to enable root phenotyping (Jeudy et al. 2016). The core of the RhizoTubes $($ ) was filled with an inert substrate (i.e. $60 \%$ attapulgite and $40 \%$ clay pebbles). The liquid inoculant was applied at root emergence (3 days after sowing) with at least $10^{5}$ and $10^{6}$ viable rhizobia per seed, for small and large seeded legumes, respectively. Plants were watered three times a day with $50 \mathrm{~mL}$ of nutrient solution the first six days and five times a day with $150 \mathrm{~mL}$ for the rest of the experiment. The nutrient solution $\left(0.80 \mathrm{mM} \mathrm{K}_{2} \mathrm{HPO}_{4}, 1.00 \mathrm{mM} \mathrm{MgSO}_{4}\right.$, $2.5 \mathrm{mM} \mathrm{CaCl}_{2}, 0.7 \mathrm{mM} \mathrm{K}_{2} \mathrm{SO}_{4}, 0.20 \mathrm{mM} \mathrm{NaCl}, 50 \mu \mathrm{M}$ iron Fe III-(EDTA), $32 \mu \mathrm{M} \mathrm{H}_{3} \mathrm{BO}_{3}, 10 \mu \mathrm{M} \mathrm{MnSO} 4,0.77 \mu \mathrm{M}$ $\mathrm{ZnSO}_{4}, 0.15 \mu \mathrm{M} \mathrm{H}{ }_{24} \mathrm{~N}_{6} \mathrm{O}_{24} \mathrm{Mo}_{7}$ and $\left.0.32 \mu \mathrm{M} \mathrm{CuSO} 4\right)$ contained only traces of $\mathrm{N}$, to ensure symbiotic $\mathrm{N}_{2}$ fixation was the only $\mathrm{N}$ source. During the $16 \mathrm{~h}$ photoperiod, plants were continuously illuminated with a lower threshold of 
$300 \mu \mathrm{mol} \mathrm{m} \mathrm{m}^{-2} \mathrm{~s}^{-1}$ provided by supplemental illumination using $400 \mathrm{~W}$ lamps (HPS Plantastar, OSRAM, Munich, Germany) when incident solar radiation dropped below $300 \mathrm{~W} \mathrm{~m}^{-2}$. Mean day and night temperatures were $22 \pm 1{ }^{\circ} \mathrm{C}$ and $19 \pm 1^{\circ} \mathrm{C}$, respectively.

\subsubsection{Sampling}

In the first year of each field experiment (2014 and 2016), shoot samples of legume and cereal (in both $\mathrm{N}$-fertilized and unfertilized treatments) were collected at physiological maturity, in the central rows of the plot, on subplots of $1 \mathrm{~m}^{2}$ to avoid hedge effect. After this stage, no more dry matter accumulation occurs in the seed and seed water content is below $55 \%$ and $35 \%$ for legumes and cereals, respectively. After separating seed and straw, samples were oven-dried for $48 \mathrm{~h}$ at $80^{\circ} \mathrm{C}$ to determine dry matter. Samples were milled and $\mathrm{N}$ concentration and ${ }^{15} \mathrm{~N}$ enrichment were measured using a mass spectrometer combined with an elemental analyzer (ANCA-GLS, Sercon Ltd., Crewe, UK). For both years, the cellulose and soluble compound concentrations of shoot residues (i.e. straw) were determined using a standard procedure (AFNOR 2018) derived from the method proposed by Van Soest (1963).

In the years following legumes and $\mathrm{N}$-fertilized cereals (2015 and 2017), wheat shoots were sampled at physiological maturity on subplots of $1 \mathrm{~m}^{2}$ to determine shoot dry matter and $\mathrm{N}$ concentration, using the same analysis method as previously described.

During the greenhouse experiment, root images were taken five times a week to monitor root expansion. Maximum root lateral expansion was measured using Matlab (2015), and lateral expansion rate (Ler) against time was calculated by linear regression analysis. Legume plants were harvested 27 days after sowing (late vegetative stage). Shoots, roots and nodules were separated and oven-dried to determine the dry matter of the different organs.

\section{$2.3 \mathrm{~N}$ pools}

A set of five $\mathrm{N}$ pools for the ten legumes and the two Nfertilized cereals (i.e. proxy of $\mathrm{N}$ functions) was determined during the two field experiments (Table 2). Cereals were used as a baseline to contrast the range of values measured for legumes with those measured for cereals cultivated under the same pedoclimatic conditions. All $\mathrm{N}$ pools were calculated in $\mathrm{kg} \mathrm{N} \mathrm{ha}{ }^{-1}$ :

- The total amount of $\mathrm{N}$ in legume and cereal seeds (Nseed), characterizes the provisioning service, through the process of $\mathrm{N}$ accumulation in seeds. In 2014 and 2016, Nseed was calculated by multiplying seed dry matter by seed $\mathrm{N}$ concentration, both measured at legume and cereal physiological maturity;

- The total amount of $\mathrm{N}$ in legume shoots derived from the air (Ndfa) over the legume growth cycle underpins the supporting service of $\mathrm{N}$ supply to legumes, through the symbiotic $\mathrm{N}_{2}$ fixation process. In 2014 and 2016, Ndfa was calculated at legume physiological maturity by multiplying the total amount of $\mathrm{N}$ in shoots by the percentage of $\mathrm{N}$ derived from the air (\%Ndfa). For each legume, $\%$ Ndfa was calculated by isotopic dilution, using the following equation (1) (Rennie and Rennie 1983):

$\% N d f a=100 \times \frac{\delta^{15} \mathrm{~N} \text { non fixing reference crop }-\delta^{15} \mathrm{~N} \text { legume }}{\delta^{15} \mathrm{~N} \text { non fixing reference crop- } \mathrm{B}}$

where $\delta^{15} \mathrm{~N}$ legume is shoot ${ }^{15} \mathrm{~N}$ enrichment of the legume crop, $\delta^{15} \mathrm{~N}$ non-fixing reference crop is that of barley or sorghum in the unfertilized $\mathrm{N}$ treatment; and $\mathrm{B}$ is the isotopic fractionation factor associated with symbiotic $\mathrm{N}_{2}$ fixation processes. Reported observed values range from -0.5 to -1.5 , varying with species, plant age and growing stage, (Unkovich and Pate 2000). Due to ${ }^{15} \mathrm{~N}$ supply in our experiment, $\delta^{15} \mathrm{~N}$ enrichment of the soil was increased in average to 41.3 , as measured by $\delta^{15} \mathrm{~N}$ of non-fixing reference crop at maturity. Therefore, compared to soil $\delta^{15} \mathrm{~N}$ enrichment, $B$ value can be neglected in equation (1). It was thus set to zero, as suggested by Rennie and Rennie (1983) when using the isotope dilution method. Stabilization of soil $\delta^{15} \mathrm{~N}$ over time was assessed by collecting shoot samples of the reference cereals (barley and sorghum) five times over their growth cycle.

For the two $\mathrm{N}$ fertilized cereals, Ndfa was set to zero as cereals have no access to atmospheric $\mathrm{N}_{2}$.

- The total amount of $\mathrm{N}$ in wheat shoots (Nwheat) cultivated after legumes and cereals characterizes the supporting service of $\mathrm{N}$ supply to the following crop by legume and cereal pre-crops. The total amount of $\mathrm{N}$ in the following wheat does not directly provide the amount of $\mathrm{N}$ derived from pre-crop residue mineralization process. However, as wheat was not $\mathrm{N}$ fertilized, the differences in the amounts of $\mathrm{N}$ in wheat shoots between pre-crop treatments (ten legumes and two cereals) partially revealed differences in the residue $\mathrm{N}$ mineralization among precrops. The total amount of $\mathrm{N}$ accumulated in wheat over its growth cycle was calculated by multiplying the amount of shoot dry matter by the shoot $\mathrm{N}$ concentration measured at wheat physiological maturity in 2015 and 2017;

- The total amount of $\mathrm{N}$ in legume and cereal shoots derived from the soil (Ndfsoil), characterizes the ability of legumes and cereals to take up soil $\mathrm{N}$ during their cycle. Ndfsoil was considered as an indicator of the amount of inorganic $\mathrm{N}$ that was not lost by leaching or gas emissions 


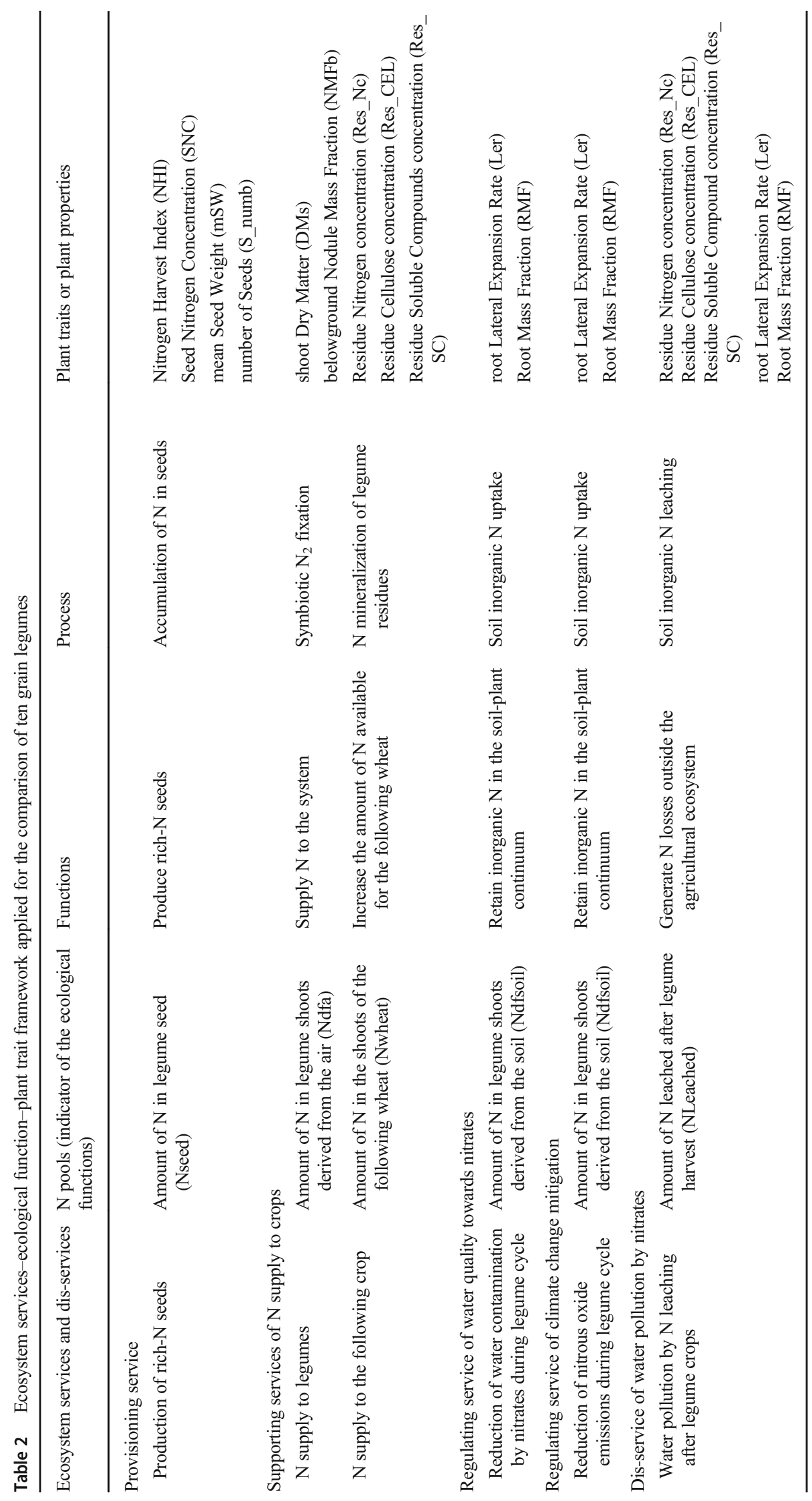


during the legume and cereal cycle, thus contributing to the regulating services of water quality towards nitrates and climate change mitigation. It was assumed that higher was the amount of $\mathrm{N}$ left in the soil after legume harvest (i.e. low ability of crop to uptake soil N), higher was the risk of $\mathrm{N}$ losses under rainy conditions. Ndfsoil was calculated at legume physiological maturity in 2014 and 2016, by subtracting the amount of $\mathrm{N}$ in legume shoots derived from the air (Ndfa) from the total amount of $\mathrm{N}$ in legume shoots. For $\mathrm{N}$ fertilized cereals, the amount of $\mathrm{N}$ derived from the soil (Ndfsoil) was distinguished from the amount of $\mathrm{N}$ derived from the fertilizer (Ndffertilizer). For both years (2014 and 2016), at cereal physiological maturity the amount of $\mathrm{N}$ in unfertilized cereals was subtracted from the total amount of $\mathrm{N}$ of the same cereal fertilized with $\mathrm{N}$, in order to estimate the amount of $\mathrm{N}$ derived from the fertilizer. The amount of $\mathrm{N}$ derived from the soil was assumed to be similar between the $\mathrm{N}$-fertilized cereal and the unfertilized cereal. For legumes, Ndffertilizer was set to zero as no $\mathrm{N}$ fertilization was applied.

- The total amount of $\mathrm{N}$ leached between the legume or the cereal pre-crop harvest and the wheat harvest (NLeached) is an indicator of the potential dis-service of water pollution by nitrates. The amount of $\mathrm{N}$ leached was simulated with the agronomic model STICS (Brisson et al. 2003) for the ten legume and the two cereal pre-crops for both experiments I (2014-2015) and II (2016-2017). A complete description of the model initialization and the simulations is available in Guinet (2019).

\subsection{Explanatory plant traits and plant properties}

Several plant traits and plant properties considered as explanatory for the different $\mathrm{N}$ functions considered here were measured for the ten grain legumes during the two field experiments and the greenhouse experiment (Table 2).

\subsubsection{Explanatory plant properties of $\mathrm{N}$ accumulation in legume seeds}

The total amount of $\mathrm{N}$ in legume seeds varies according to seed mass and seed $\mathrm{N}$ content. Two plant properties were considered as explanatory for seed mass: i) the number of seeds per square meter ( $\mathrm{S}$ num), and ii) mean seed weight $(\mathrm{mSW})$. Two additional plant properties were considered as explanatory for the plant investment of $\mathrm{N}$ in seeds: i) seed nitrogen concentration (SNC) and ii) nitrogen harvest index (NHI), calculated as the ratio between the total amount of $\mathrm{N}$ in seeds and the total amount of $\mathrm{N}$ in shoots (straw + seed).

\subsubsection{Explanatory plant traits and properties of $\mathrm{N}$ supply to crops}

The $\mathrm{N}$ requirement for growth is considered as one of the main drivers of the amount of atmospheric $\mathrm{N}_{2}$ fixed by legumes (Anglade et al. 2015). Thus, shoot dry matter (DMs) was measured at legume physiological maturity to characterize legume crop $\mathrm{N}$ requirements for growth. In addition, the belowground nodule mass fraction (NMFb), calculated as the ratio between nodule biomass and belowground biomass (nodule + root), was measured on plants cultivated in RhizoTubes $\odot$. This latter trait characterizes the tradeoff in biomass distribution between the two organs that enable the acquisition of $\mathrm{N}$ by legumes: nodules (for symbiotic $\mathrm{N}_{2}$ fixation) and roots (for soil $\mathrm{N}$ uptake). Root traits values can be found in Guinet et al. (2018).

Residue $\mathrm{N}$ mineralization is considered an important process for explaining differences in the total amount of $\mathrm{N}$ in shoots of wheat cultivated after the ten grain legumes. Many studies have highlighted the effect of residue biochemical characteristics on residue $\mathrm{N}$ mineralization (Kumar and Goh 2003) Three biochemical characteristics were selected to explain the differences in legume residue $\mathrm{N}$ mineralization and consequently the amount of $\mathrm{N}$ in the following wheat: i) residue nitrogen concentration (Res_Nc), ii) residue cellulose concentration (Res_CEL) and iii) residue soluble compound concentration (Res_SC).

\subsubsection{Explanatory plant traits of $\mathrm{N}$ losses mitigation}

Soil $\mathrm{N}$ uptake by legumes modulates the amount of $\mathrm{N}$ left in the soil and potentially lost by leaching or gas emissions. The amount of soil $\mathrm{N}$ taken up by legumes varies according to the ability of the root system to explore the soil. Root lateral expansion rate (Ler) has been highlighted as a determinant for explaining the differences in soil $\mathrm{N}$ uptake within a wide range of legume species (Guinet et al. 2018). Root mass fraction (RMF), calculated as the ratio between root biomass and the total plant biomass, characterizes the investment of plant biomass in roots (i.e. the organs enabling soil $\mathrm{N}$ uptake). Both latter traits were measured on plants cultivated in RhizoTubes@ because of the difficulty to measure these traits in field experiments.

\subsubsection{Explanatory plant traits and properties of $\mathrm{N}$ leaching}

The amount of $\mathrm{N}$ leached after legume harvest depends on the amount of inorganic $\mathrm{N}$ in the soil after harvest, which is potentially modulated by the ability of legumes to take up soil inorganic $\mathrm{N}$, and by legume residue $\mathrm{N}$ mineralization. Thus, plant traits and plant properties affecting soil $\mathrm{N}$ uptake by legumes and residue $\mathrm{N}$ mineralization were considered as 
explanatory plant traits of the amount of $\mathrm{N}$ leached after legume harvest (section 2.4.2 and 2.4.3).

\subsection{Calculation of multifunctionality}

The multiple threshold approach suggested by Byrnes et al. (2014) was applied to assess the multifunctionality of the ten grain legumes using the five $\mathrm{N}$ pools described above (Nseed, Ndfa, Nwheat, Ndfsoil, Nleached). The objective of this approach is to provide an index for each legume species, to assess their ability to deliver multiple ecosystem services relative to $\mathrm{N}$.

First, values of Nleached were transformed using equation 2 to capture the desired direction of the effect (i.e. high transformed values indicate low $\mathrm{N}$ losses by leaching).

Nleached $\_i, x=-$ Nleached $i, x+\max ($ Nleached $x)$

where Nleached $i, x$ is the amount of $\mathrm{N}$ leached between the harvest of legume $\mathrm{i}$ and the harvest of the following wheat in experiment $\mathrm{x}$ (Experiment I or II); $\max ($ Nleached $x$ ) is the maximal amount of $\mathrm{N}$ leached considering all legume precrops in experiment $x$ (i.e. $123 \mathrm{~kg} \mathrm{~N}^{-1}$ after the common vetch harvest in experiment I and $49 \mathrm{~kg} \mathrm{~N} \mathrm{ha}^{-1}$ after the common vetch harvest in experiment II).
The multifunctionality index was calculated at different thresholds, ranging from 5 to $100 \%$ of the maximum values observed for each $\mathrm{N}$ pool. The maximum value was the mean of the nine highest observations for each $\mathrm{N}$ pool across all legume treatments and experiments. The multifunctionality index corresponds to the number of $\mathrm{N}$ pools that simultaneously exceed a given threshold. For example, a treatment would receive a multifunctionality score of 5 for the $50 \%$ threshold if Nseed was higher than $156 \mathrm{~kg} \mathrm{~N}^{-1}$, Ndfa was higher than $156 \mathrm{~kg} \mathrm{~N}^{-1}$, Nwheat was higher than $47 \mathrm{~kg} \mathrm{~N}$ $\mathrm{ha}^{-1}$, Ndfsoil was higher than $43 \mathrm{~kg} \mathrm{~N} \mathrm{ha}^{-1}$, and Nleached_r was higher than $34 \mathrm{~kg} \mathrm{~N}^{-1}$ (Fig. 2). For each legume species, the multifunctionality index was calculated without distinguishing the two field experiments. Since chickpea had no seed production in 2014 whereas it did in 2016, the multifunctional index was calculated separately for both experiments.

\subsection{Contribution of legumes to soil $\mathrm{N}$}

The potential benefit of grain legumes for soil $\mathrm{N}$ (i.e., the net $\mathrm{N}$ balance) is calculated as the difference between the amount of $\mathrm{N}$ derived from the air (Ndfa) and the amount of $\mathrm{N}$ in legume seed (Nseed) (Evans et al. 2001). A positive net $\mathrm{N}$ balance indicates an input of $\mathrm{N}$ to the soil due to the symbiotic $\mathrm{N}_{2}$
Fig. $2 \mathrm{~N}$ pool ranges for legumes (gray) and $\mathrm{N}$-fertilized cereals (white), measured during two field experiments lasting 2 years. Amount of $\mathrm{N}$ in seed (Nseed); amount of $\mathrm{N}$ in shoots derived from the air (Ndfa); amount of $\mathrm{N}$ in shoots derived from the soil (Ndfsoil); amount of $\mathrm{N}$ in shoots derived from the fertilizer (Ndffertilizer); amount of inorganic $\mathrm{N}$ leached between the pre-crop harvest and the harvest of the following wheat (NLeached); amount of $\mathrm{N}$ in the shoots of the following wheat (Nwheat). The red edges of the boxplot indicate that only legumes with seed production were considered. For Nseed, Ndfsoil, Nleached, and Nwheat, $* p<0.001$ indicates a significant difference between legumes and cereals, and for Ndfa and Ndffertilizer a significant difference with zero

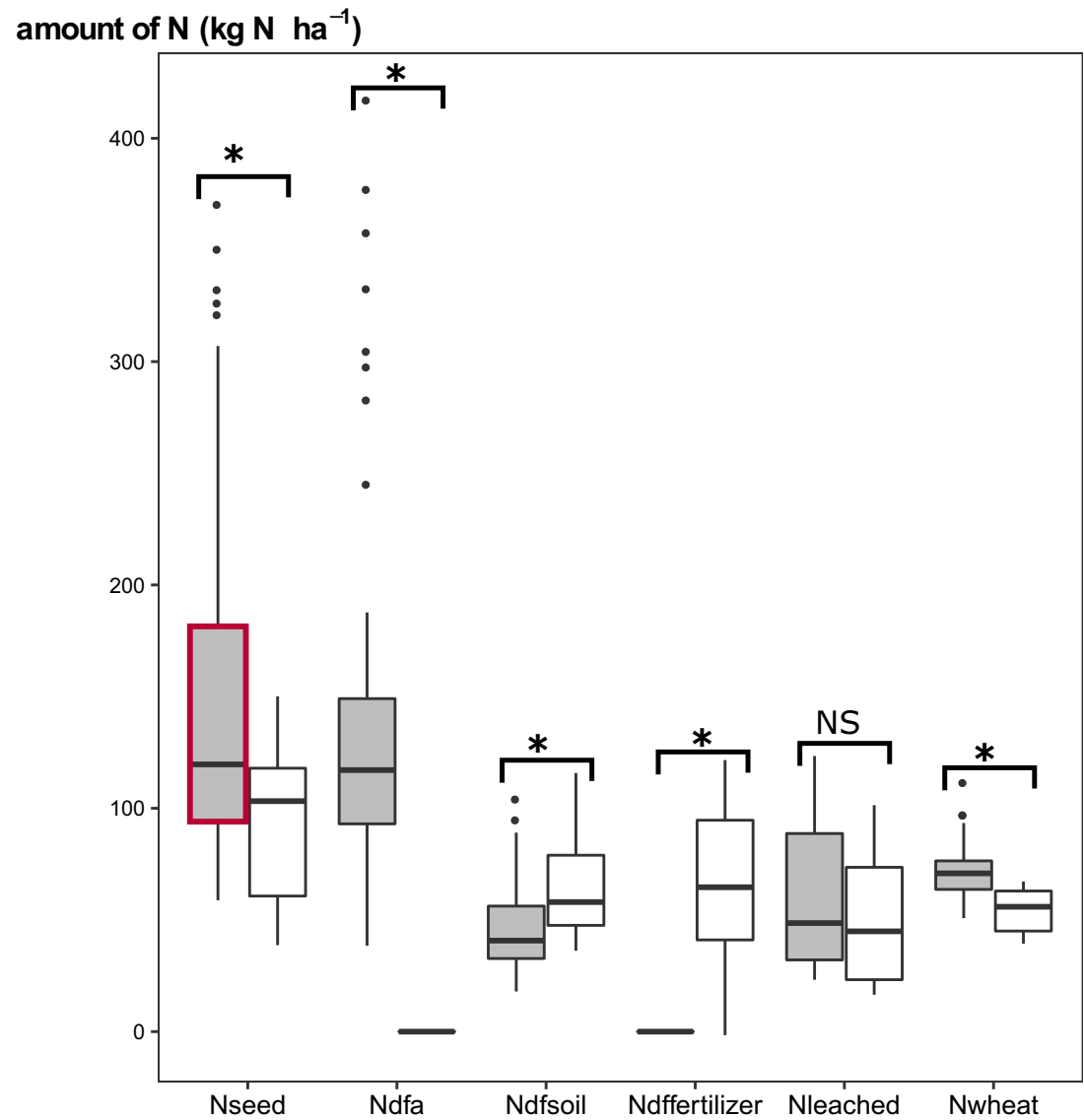


fixation process. The net $\mathrm{N}$ balance was calculated in 2014 and 2016 for each of the ten grain legumes.

\subsection{Data analysis}

All calculations and data analyses were performed with $\mathrm{R}$ version 3.5.1. (R Development Core Team 2016).

Each N pool was regressed against all crop species (both legumes and $\mathrm{N}$-fertilized cereals) to ensure the precise estimation of the performance of each crop and meet assumptions of linear regression. Custom contrasts were adjusted with the \{emmeans\} package version 1.3.4 to test two hypotheses: (i) all crop species show similar performance and (ii) the average performance of all legume species is similar to the average performance of $\mathrm{N}$-fertilized cereal species. Cereals were removed from the dataset for the analysis of Ndfa, since $\mathrm{N}_{2}$ fixation is not relevant for cereals (i.e., equal to zero, no variability). Likewise, legumes were removed from the dataset for the analysis of Ndffertilizer because no $\mathrm{N}$ fertilization was applied on legumes. In these two cases, the average performances of legume and cereal crops were simply compared with zero.

Two-way analysis of variance (ANOVA) was performed to test for year, legume species, and year $\times$ legume species interaction effects on each of the five $\mathrm{N}$ pools. Normality and homoscedasticity assumptions were visually assessed through quantile-quantile (QQ) and residual vs. fitted plots, respectively. If the effects were significant, contrasts among pre-crops were adjusted using the package \{emmeans\} version 1.3.4.

The multifunctionality index was calculated using the "getFuncsMaxed" function from the \{multifunc\} package developed by Byrnes et al. (2014).

A redundancy analysis was performed to determine the synergy and trade-off between $\mathrm{N}$ functions (approximated by $\mathrm{N}$ pools) and identify plant traits and properties that best explained the variability of $\mathrm{N}$ functions among the ten grain legume species. $\mathrm{N}$ functions were considered as the response variables while plant traits and plant properties were considered as the explanatory variables. The net $\mathrm{N}$ balance was added in the RDA as a supplementary variable. The effect of plant traits and plant properties on $\mathrm{N}$ functions was tested using a Monte Carlos permutation test (999 permutations). The RDA was performed using Canoco v. 5.10 (Šmilaueur and Lepš 2014) on the variables standardized beforehand.

\section{Results and Discussion}

\section{$3.1 \mathrm{~N}$ pool variability}

In comparison with $\mathrm{N}$-fertilized cereals, on average legumes exported 55\% more $\mathrm{N}$ in seeds (Nseed; contrast on legumescereals, estimate $=51.5, \mathrm{SE}=12.9, d f=69, t$-ratio $=3.99$, $p<0.001$ ) and led to $30 \%$ more $\mathrm{N}$ in the following wheat (Nwheat; contrast on legumes-cereals, estimate $=16.3, \mathrm{SE}=$ 2.29, $d f=79, t$-ratio $=7.12, p<0.001$; Fig. 2). Conversely, soil $\mathrm{N}$ uptake by legumes was $27 \%$ less than by cereals (contrast on legumes-cereals, estimate $=-17.7, \mathrm{SE}=3.08, d f=$ $79, t$-ratio $=-5.74, p<0.001)$. Legumes can also be distinguished from cereals according to their $\mathrm{N}$ nutrition. In addition to soil $\mathrm{N}$ uptake, $\mathrm{N}$ requirements are either fulfilled by symbiotic $\mathrm{N}_{2}$ fixation for legumes or by $\mathrm{N}$ fertilizer uptake for cereals. No significant differences were observed regarding $\mathrm{N}$ leaching occurring after legume or cereal pre-crops. These results confirm the ecosystem services relative to $\mathrm{N}$ provided by legumes in comparison to cereals (production of N-rich seed and $\mathrm{N}$ supply to the following crops). However, they also highlight the potential higher risk of $\mathrm{N}$ losses after legumes due to their lower ability to take up soil $\mathrm{N}$ (even if in this study, no significant differences in $\mathrm{N}$ leaching between legumes and cereals were observed).

Although general differences between legumes and cereals could be determined, considerable variability among legume species and years was also highlighted for all five $\mathrm{N}$ pools (Fig. 2; Table 3). The highest variability was observed for the amount of $\mathrm{N}$ exported in legume seeds (Nseed) and for the amount of $\mathrm{N}$ in legume shoots derived from the air (Ndfa). For both $\mathrm{N}$ pools, the highest values were measured for soybean in 2014 and 2016 and for faba bean in 2016 while the lowest values were measured both years for Narbonne vetch, common bean, common vetch, and lentil. The amount of soil $\mathrm{N}$ uptake was significantly higher for soybean and common bean for both years, and for chickpea in 2016 compared with all other legume species (on average $73 \mathrm{vs} 38 \mathrm{~kg} \mathrm{~N} \mathrm{ha}^{-1}$ ). The amount of $\mathrm{N}$ leached after legume harvest was only significantly different between legumes in 2014 with common vetch, lentil, faba bean, lupin, and pea having the highest values. In 2014, the amounts of N lost by leaching were much higher compared to 2016 because of unusually high rainfall between July and November which might have exacerbated the differences between legumes. Unlike 2015, significant differences between species were highlighted for the amount of $\mathrm{N}$ in the following wheat in 2017. Faba bean and Narbonne vetch induced the highest amounts of $\mathrm{N}$ in wheat in contrast to soybean and chickpea.

Thereafter, our study focused on the ten legume species in order to (i) determine synergies and tradeoffs among the five $\mathrm{N}$ functions (approximated by $\mathrm{N}$ pools) and (ii) establish and compare the functional profiles of the ten legume species.

\subsection{Explanatory plant traits and plant properties of the $\mathrm{N}$ functions}

Plant traits and plant properties explained $76.1 \%$ of the $\mathrm{N}$ pool variability. On the first two axes of the RDA, $66.1 \%$ of the $\mathrm{N}$ pools variability was explained by plant traits and plant 
Table $3 \mathrm{~N}$ pools as affected by legume species and years. Values are mean $(n=4)$. Lowercase letters refer to contrasts between pre-crops. Mean value sharing the same letter ('a' and/or ' $\mathrm{b}$ ') are not different according to Tukey's test (ns: non-significant, $* p<0.05, * * p<0.01, * * * p<0.001$ )

\begin{tabular}{|c|c|c|c|c|c|c|c|c|c|c|}
\hline & \multicolumn{2}{|l|}{ Nseed } & \multicolumn{2}{|l|}{ Ndfa } & \multicolumn{2}{|c|}{ Ndfsoil } & \multicolumn{2}{|c|}{ Nleached } & \multicolumn{2}{|c|}{ Nwheat } \\
\hline & \multicolumn{10}{|c|}{$\left(\mathrm{kg} \mathrm{N} \mathrm{ha}^{-1}\right)$} \\
\hline & 2014 & 2016 & 2014 & 2016 & 2014 & 2016 & 2014 & 2016 & 2015 & 2017 \\
\hline Chickpea & & $167 \mathrm{c}$ & $117 \mathrm{bc}$ & $140 \mathrm{bc}$ & $40 \mathrm{~b}$ & $84 \mathrm{a}$ & $59 \mathrm{~b}$ & 23 & 64 & $64 c$ \\
\hline Common bean & $126 \mathrm{c}$ & $99 \mathrm{~d}$ & $90 \mathrm{~cd}$ & $81 \mathrm{de}$ & $69 \mathrm{a}$ & $64 \mathrm{ab}$ & $60 \mathrm{~b}$ & 31 & 60 & $67 \mathrm{bc}$ \\
\hline Common vetch & $91 \mathrm{c}$ & $62 \mathrm{~d}$ & $100 \mathrm{~cd}$ & $87 \mathrm{de}$ & $43 \mathrm{~b}$ & $27 \mathrm{~d}$ & $123 \mathrm{a}$ & 49 & 67 & $79 a b c$ \\
\hline Fababean & $116 \mathrm{c}$ & 316 a & $129 \mathrm{bc}$ & $364 \mathrm{a}$ & $45 \mathrm{~b}$ & $58 \mathrm{bc}$ & $103 \mathrm{a}$ & 28 & 78 & $84 \mathrm{ab}$ \\
\hline Fenugreek & & $93 \mathrm{~d}$ & & $119 \mathrm{~cd}$ & & $29 d$ & & 30 & & $70 \mathrm{bc}$ \\
\hline Lentil & $93 \mathrm{c}$ & $93 \mathrm{~d}$ & $99 \mathrm{~cd}$ & $123 \mathrm{~cd}$ & $39 \mathrm{~b}$ & $29 d$ & $122 \mathrm{a}$ & 32 & 77 & $75 a b c$ \\
\hline Lupin & $168 \mathrm{~b}$ & $177 \mathrm{bc}$ & $147 \mathrm{~b}$ & $174 \mathrm{~b}$ & $38 \mathrm{~b}$ & $39 \mathrm{~cd}$ & $91 \mathrm{a}$ & 35 & 74 & $65 \mathrm{bc}$ \\
\hline Narbonne vetch & & & $60 \mathrm{~d}$ & $72 \mathrm{e}$ & $30 \mathrm{~b}$ & $39 \mathrm{~cd}$ & $77 \mathrm{ab}$ & 44 & 76 & $93 \mathrm{a}$ \\
\hline Pea & $130 \mathrm{bc}$ & $88 \mathrm{~d}$ & $112 \mathrm{bc}$ & $113 \mathrm{cde}$ & $44 \mathrm{~b}$ & $31 \mathrm{~d}$ & 89 a & 45 & 70 & $66 \mathrm{bc}$ \\
\hline Soybean & $327 \mathrm{a}$ & $216 \mathrm{~b}$ & $290 \mathrm{a}$ & $172 \mathrm{~b}$ & $67 \mathrm{a}$ & $82 \mathrm{a}$ & $48 \mathrm{~b}$ & 34 & 67 & $61 \mathrm{c}$ \\
\hline Species & $* * *$ & & $* * *$ & & $* * *$ & & $* * *$ & & $* * *$ & \\
\hline Year & $\mathrm{ns}$ & & $* * *$ & & $\mathrm{~ns}$ & & ns & & $* * *$ & \\
\hline Species * year & $* * *$ & & $* * *$ & & $* *$ & & $*$ & & $* * *$ & \\
\hline
\end{tabular}

properties $(47.3 \%$ and $18.8 \%$ on the first and second axes, respectively; Fig. 3a). Much of the $\mathrm{N}$ pool variability was explained by shoot dry matter (DMs: $38.4 \%, p=0.001$ ) while belowground nodule mass fraction (NMFb: $8.4 \%, p=0.001$ ), seed nitrogen concentration (SNC: $8.3 \%, p=0.001$ ), residue soluble compound concentration (Res_SC: $6.9 \%, p=0.001$ ), and residue nitrogen concentration (Res_Nc: $6.3 \%, p=0.001$ ) each explained between 6 and $11 \%$ of the variability. The remaining plant traits and properties each explained less than $5 \%$ of the variability of $\mathrm{N}$ pools, with only a significant effect of root lateral expansion rate (Ler: $3.1 \%, p=0.001$ ), nitrogen harvest index (NHI: $2.2 \%, p=0.002$ ), and root mass fraction (RMF: $1.0 \%, p=0.049$ ).

\subsection{Synergy between seed $N$ and $N_{2}$ fixation}

The RDA biplot highlighted a clear positive correlation between the amount of $\mathrm{N}$ in legumes derived from the air (Ndfa) and the amount of $\mathrm{N}$ in legume seeds (Nseed; Fig. 3a). Both $\mathrm{N}$ pools were positively correlated with four plant traits: legume shoot dry matter (DMs), nitrogen harvest index (NHI), mean seed weight $(\mathrm{mSW})$, and seed $\mathrm{N}$ concentration (SNC). The amount of $\mathrm{N}$ accumulated in legume seeds (Nseed) first depends on plant growth, which drives the plant's $\mathrm{N}$ requirements and its accumulation of $\mathrm{N}$. Based on the variation among species and experiments, the positive relationship between the amount of $\mathrm{N}$ fixed by legumes and legume shoot dry matter led to a mean value of $25 \mathrm{~kg}$ of $\mathrm{N}$ fixed for every ton of shoot dry matter. This value is equivalent to the maximum value reported by Peoples et al. (2019). Second, the amount of $\mathrm{N}$ in seeds depends on the amount of $\mathrm{N}$ remobilized from vegetative organs to seeds during seed filling at the end of the plant growth cycle (Schiltz et al. 2005). The latter process seems to be modulated by seed size and seed $\mathrm{N}$ concentration.

\subsection{Underlying $\mathbf{N}$ functions of legumes affecting the performances of the following wheat}

When considered independently, the amount of $\mathrm{N}$ derived from the air (Ndfa) and the amount of $\mathrm{N}$ in legume seeds (Nseed) were not correlated with the amount of $\mathrm{N}$ in the following wheat (Nwheat; Fig. 3a). However, a positive relationship was highlighted between the amount of $\mathrm{N}$ in the following wheat and the net $\mathrm{N}$ balance (i.e., calculated as the difference between Ndfa and Nseed). Thus, the contribution of legumes to soil $\mathrm{N}$ through the symbiotic $\mathrm{N}_{2}$ fixation process increases the amount of $\mathrm{N}$ in the following wheat.

Situations enhancing the symbiotic $\mathrm{N}_{2}$ fixation process tend to induce a positive net $\mathrm{N}$ balance (Evans et al. 2001). The increase of symbiotic $\mathrm{N}_{2}$ fixation occurs when little soil $\mathrm{N}$ is available during the legume growth cycle, as most legume $\mathrm{N}$ requirements are then fulfilled through the symbiotic $\mathrm{N}_{2}$ fixation process. Likewise, legume species with low ability to take up soil $\mathrm{N}$ mostly rely on the symbiotic $\mathrm{N}_{2}$ fixation process to fulfill their $\mathrm{N}$ requirements (Guinet et al. 2018). Therefore, the higher the legume uptake of soil $\mathrm{N}$ during the growth cycle (Ndfsoil), the lower the net $\mathrm{N}$ balance and thus the amount of $\mathrm{N}$ in the following wheat (Nwheat; Fig. 3a). As expected, the amount of soil $\mathrm{N}$ taken up by legumes (Ndfsoil) 
Fig. 3 a Redundancy analysis (RDA) biplot on the first two axes, illustrating the relationship between $\mathrm{N}$ pools (response variables: thick dark blue arrows) and plant traits and properties (explanatory variables: fine light blue arrows). The apparent $\mathrm{N}$ balance was added as an explanatory variable (purple dotted arrow). Nitrogen harvest index (NHI); seed nitrogen concentration (SNC); mean seed weight (mSW); number of seeds (S_numb); shoot dry matter (DMs); belowground nodule mass fraction (NMFb); residue nitrogen concentration (Res_Nc); residue cellulose concentration (Res_CEL); residue soluble compound concentration (Res $\mathrm{SC}$ ); root lateral expansion rate (Ler); root mass fraction (RMF). Amount of $\mathrm{N}$ in legume seed (Nseed); amount of $\mathrm{N}$ in legume shoots derived from the air (Ndfa); amount of $\mathrm{N}$ in the shoots of the following wheat (Nwheat); amount of $\mathrm{N}$ in legume shoots derived from the soil (Ndfsoil); amount of $\mathrm{N}$ leached after legume harvest (NLeached). b Scatter diagram with the first two axes of the RDA. The ellipses represent a 95\% confidence interval for each legume species and both experiments: experiment I: ( $\mathbf{\Delta})$ and experiment II $(\diamond)$. Species for which there was no seed production are indicated by cc: cover-crops axis $2(18.8 \%)$

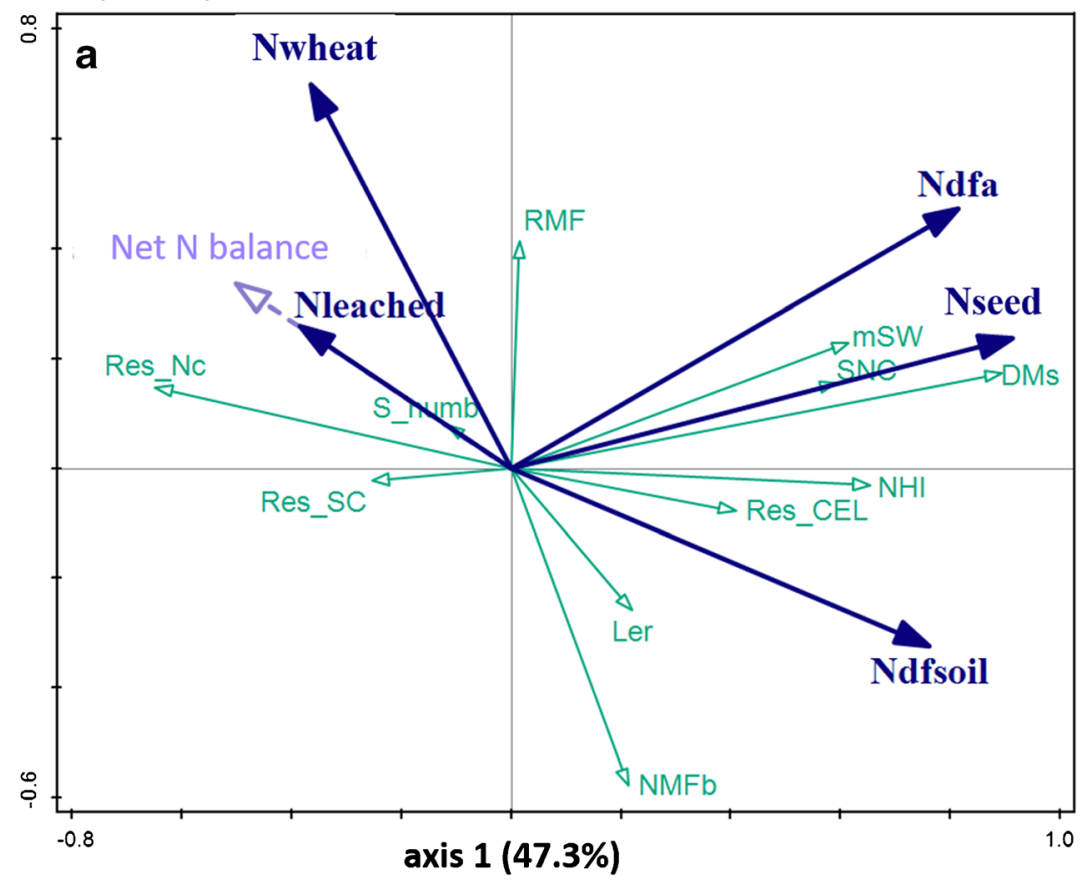

axis 2 (18.8\%)

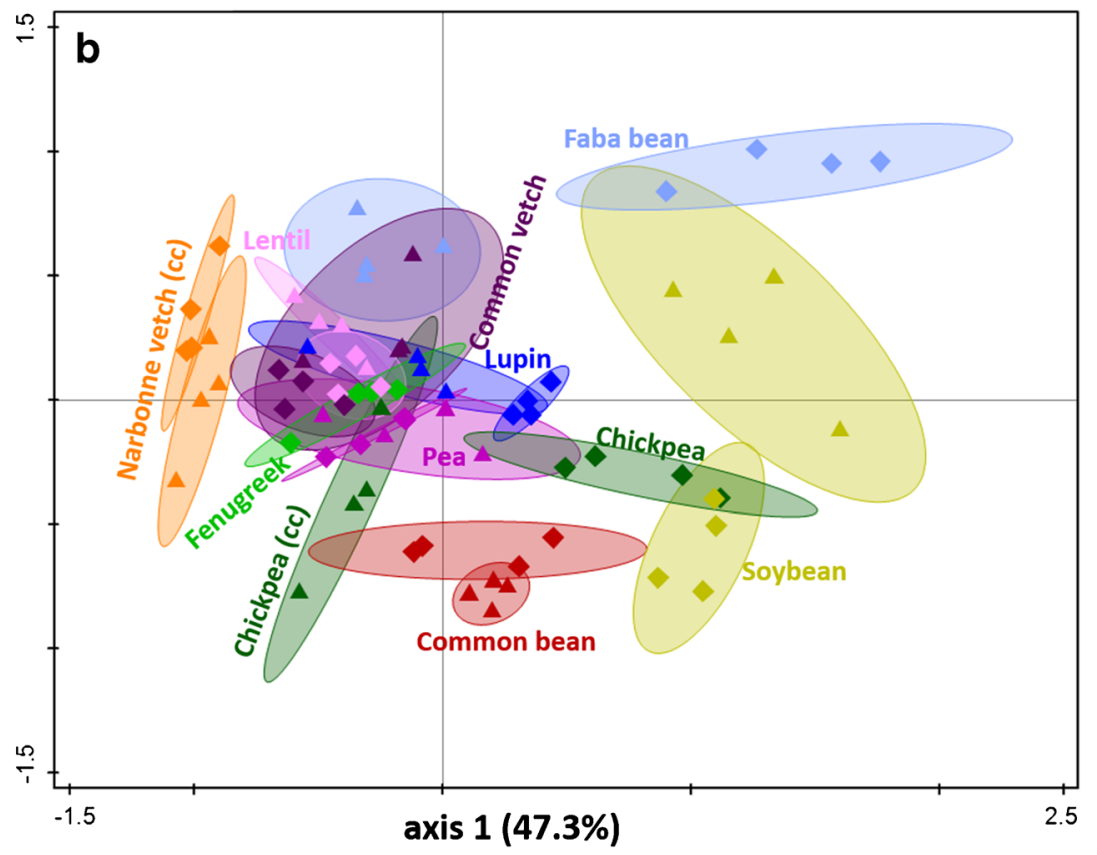

was positively correlated with the root lateral expansion rate (Ler). Ndfsoil was also positively correlated with the belowground nodule mass fraction (NMFb), considered as a proxy for $\mathrm{C}$ allocation trade-off between roots and nodules. A high biomass allocation to nodules reflects a high $\mathrm{C}$ cost associated with nodule establishment, maintenance, and metabolism, but with a depressive effect on root and shoot development (Bourion et al. 2007). This tradeoff suggests that legumes for which nodules induce a high $\mathrm{C}$ cost (high $\mathrm{NMFb}$ ) primarily take up soil $\mathrm{N}$ through the development of their root system in order to minimize the $\mathrm{C}$ cost associated with $\mathrm{N}$ acquisition. Conversely, no relation was established between the amount of soil $\mathrm{N}$ taken up by legumes (Ndfsoil) and root mass fraction (RMF). As highlighted by Dunbabin et al. (2003) plant traits characterizing root architecture may be more appropriate for explaining the differences in the ability of legumes to take up soil $\mathrm{N}$, than simply considering root biomass. 
High amounts of $\mathrm{N}$ derived from the air (Ndfa) are not sufficient to ensure a positive net $\mathrm{N}$ balance. For a given amount of $\mathrm{N}$ derived from the air (Ndfa), the net $\mathrm{N}$ balance results from the tradeoff between $\mathrm{N}$ exported in legume seeds and $\mathrm{N}$ supply to the soil by legume straws left in the field. Legumes having a high seed $\mathrm{N}$ concentration (SNC) also have straws characterized by low N concentrations (Res_Nc) and high fractions of structural polysaccharides such as cellulose (Res_CEL; Fig. 3a). Consequently, straws having a lower N mineralization potential (Palm et al. 2001), thus, release less inorganic $\mathrm{N}$ for the following wheat to take up. Residue $\mathrm{N}$ mineralization results from the interaction between climatic conditions, soil physical, chemical and biological characteristics, and residue biophysical characteristics. Thus, the provision of $\mathrm{N}$ to the following crops through residue mineralization is highly complex compared with synthetic fertilizer provisions, leading to a potential desynchronization between $\mathrm{N}$ supply and $\mathrm{N}$ requirement of the following crop. However, residue $\mathrm{N}$ incorporated in soil organic matter contributes to long-term soil fertility (Palmer et al. 2017).

\subsection{Tradeoff between soil $\mathrm{N}$ uptake and $\mathrm{N}$ leaching}

We found a clear negative correlation between the amount of $\mathrm{N}$ in legume shoots derived from the soil (Ndfsoil) and the amount of $\mathrm{N}$ leached after the legume harvest (Nleached; Fig. 3a). In accordance with Plaza-Bonilla et al. (2015), this relationship indicates that legume species with a good ability to take up soil $\mathrm{N}$ during their growth cycle reduce the risk of $\mathrm{N}$ leaching after their harvest by decreasing the amount of inorganic $\mathrm{N}$ left in the soil. Our experimental site is characterized by frequent rain episodes during the autumn-winter period. During this same period, because the soil is either left bare or cropped with the following wheat at its early stages, with only very low $\mathrm{N}$ requirements, the inorganic $\mathrm{N}$ left in the soil after the legume harvest is greatly exposed to $\mathrm{N}$ leaching. Nitrogen leaching to groundwater aquifers and rivers causes water pollution and eutrophication (Palmer et al. 2017). In waterlogged soils, denitrification of soil inorganic $\mathrm{N}$ left after legume crops might also generate nitrous oxide emissions. Nitrous oxide is a major greenhouse gas contributor to climate change (Peoples et al. 2019). Thus, while increasing soil $\mathrm{N}$ after legumes can positively influence the supporting service of $\mathrm{N}$ supply to the following wheat, it may also generate disservices associated with $\mathrm{N}$ losses.

However, considerable losses of $\mathrm{N}$ by leaching do not necessarily lead to the smallest amounts of $\mathrm{N}$ in the following crop, as shown by the positive relationship between the amount of $\mathrm{N}$ leached after the legume harvest (Nleached) and the amount of $\mathrm{N}$ in the following wheat (Nwheat; Fig. $3 a)$. Even when a proportion of soil $\mathrm{N}$ is leached after legume harvest, the $\mathrm{N}$ requirements of the following wheat can also be covered by soil and residue organic $\mathrm{N}$ mineralization. The latter two processes mainly occur during the spring period, as temperatures rise. During the spring, the significant $\mathrm{N}$ requirements of the following wheat ensure the uptake of $\mathrm{N}$ released by these two processes and contribute to reducing $\mathrm{N}$ leaching in comparison with the autumn-winter period.

\subsection{Functional profiles of the ten grain legumes}

For the first time, ten grain legume species were evaluated in the same pedoclimatic conditions. They were characterized by contrasted functional profiles relative to $\mathrm{N}$ functions (Fig. 3b, Table 3). On the one hand, chickpea in 2016 (i.e., with seed production), common bean, and soybean had a high ability to take up soil $\mathrm{N}$ during their growth cycles (Ndfsoil). As a consequence, they limited the potential dis-service of water pollution by nitrates thanks to the low $\mathrm{N}$ losses by leaching after their harvest (Nleached). Yet, these three species contributed little to the supporting service of $\mathrm{N}$ supply to the following crop, as they induced low amounts of $\mathrm{N}$ in the following wheat (Nwheat). The three latter species were characterized by a high root lateral expansion rate (Ler) and belowground nodule mass fraction (NMFb). The high ability of chickpea and common bean to take up soil $\mathrm{N}$ could partially be explained by poor symbiotic $\mathrm{N}_{2}$ fixation efficiency. In the last decades, common bean genotypes have been bred and selected in high fertility soil that likely resulted in low $\mathrm{N}_{2}$ fixation efficiency (Van Kessel and Hartley 2000). Moreover, even if chickpea was inoculated with rhizobia upon sowing, the selection of highly efficient and competitive rhizobia strains in the northeast part of France is still at stake for this species. Conversely, in our study, soybean was bred to nodulate with highly efficient rhizobia strains and seems to be able to efficiently acquire $\mathrm{N}$ from symbiotic $\mathrm{N}_{2}$ fixation and soil $\mathrm{N}$ uptake.

On the other hand, Narbonne vetch, lentil, common vetch, and faba bean had low ability to take up soil N (Ndfsoil) and induced higher amounts of $\mathrm{N}$ leaching after their harvest (Nleached), hence contributing to the dis-service of water pollution by nitrates. However, the latter legume species tended to better contribute to the supporting service of $\mathrm{N}$ supply to the following crop in comparison with chickpea, common bean, and soybean. Indeed, their high residue $\mathrm{N}$ concentrations (Res_Nc) induced higher amounts of $\mathrm{N}$ in the shoots of the following wheat.

Compared with the other species, faba bean in 2016 and soybean in 2014 had the highest amounts of $\mathrm{N}$ derived from the air (Ndfa) as well as the highest amounts of $\mathrm{N}$ in seeds (Nseed), underpinning the supporting service of $\mathrm{N}$ supply to legumes and the provisioning service. These two species were characterized by high shoot dry matter (DMs) and nitrogen harvest index (NHI).

Finally, pea and lupin had an intermediate position (i.e., a mean value for all five $\mathrm{N}$ pools in comparison with the other 
legume species), meaning that these two species enabled a compromise between the different ecosystem services and dis-services relative to $\mathrm{N}$.

\subsection{Legume multifunctionality at different levels of intensity}

For thresholds (i.e., percentage of the maximum observed level of each $\mathrm{N}$ pool) ranging between 5 and $25 \%$, chickpea considered as cover crop (cc), common vetch and Narbonne vetch (cc) had a multifunctionality index of 4 , meaning that at least one of the five $\mathrm{N}$ pools was below the $25 \%$ threshold (Fig. 4). For Narbonne vetch and chickpea cc, this was explained by the absence of seed production (i.e., the amount of
$\mathrm{N}$ in seeds was nil for these two species) while for common vetch, the high $\mathrm{N}$ losses due to leaching after harvest led to a value of zero for Nleached_r. For the same range of thresholds, all the other legume species had the maximum multifunctionality index of 5 .

For all species, the mean number of $\mathrm{N}$ pools exceeding the threshold decreased as the threshold increased, supporting the existence of trade-offs between $\mathrm{N}$ functions, and limiting the ability of grain legumes to simultaneously provide multiple ecosystem services at high levels (Blesh 2018). Hence, the choice of grain legumes must be determined according to the most desired ecosystem services. In our study, the same threshold was assigned to the five $\mathrm{N}$ pools. To go further in the assessment of ecosystem services provided by legumes,

\section{multifunctionality index}
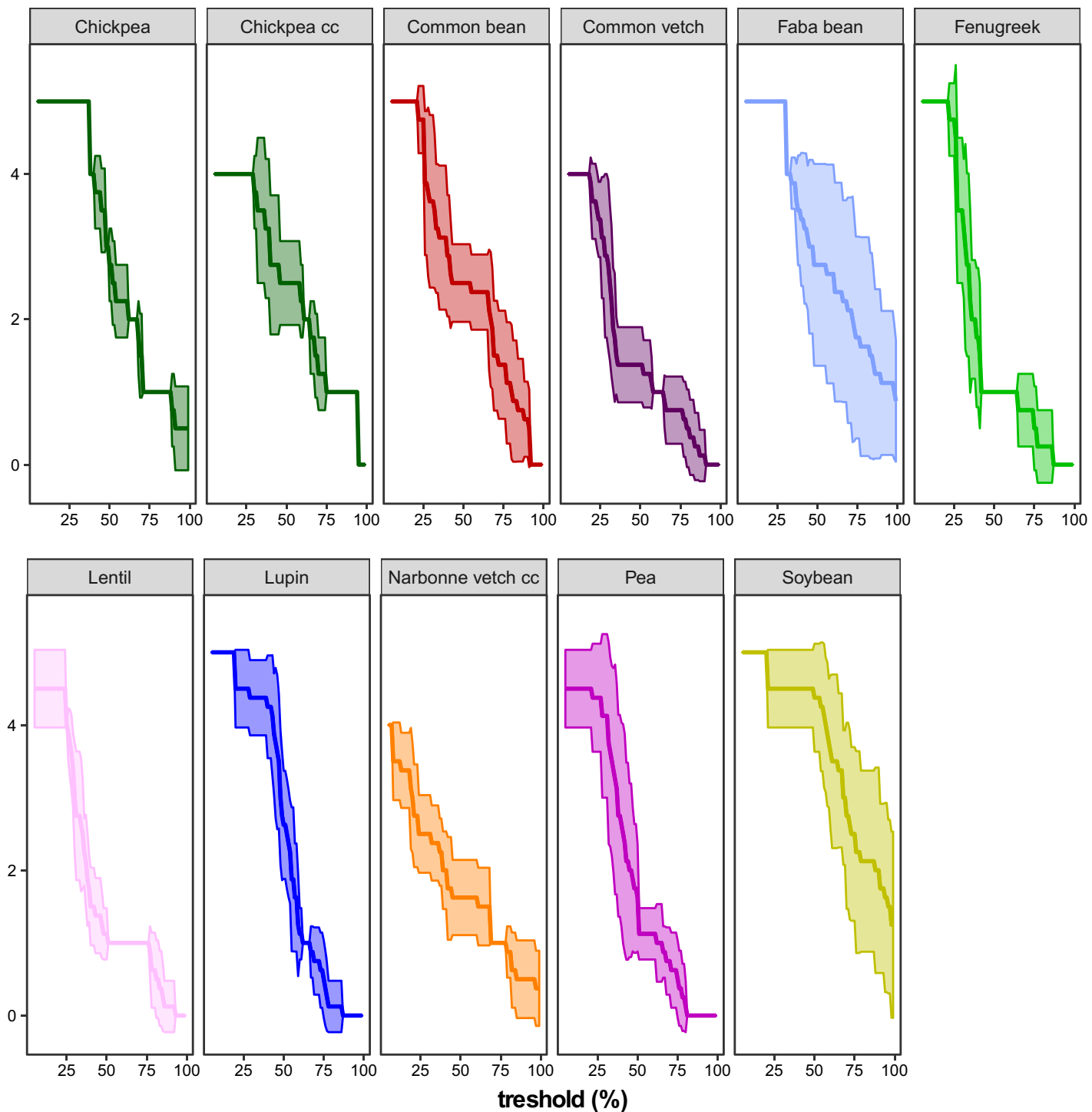

Fig. 4 Multifunctionality index for thresholds ranging from 5 to $100 \%$ for ten legume crops. The envelopes correspond to the standard deviation. Species for which there was no seed production are indicated by cc:

2014). For this reason, chickpea with seed production was distinguished from chickpea with no seed production to calculate the multifunctionality index 
collaborative work with farmers could be developed to define relevant thresholds for each $\mathrm{N}$ function, in order to select legume species according to the specific goals desired by farmers. The multifunctional index approach is an innovative way to characterize species for their differential ability to deliver multiple functions at different levels of intensity with a unique indicator.

\section{Conclusion}

In this study, the simultaneous measurements of five $\mathrm{N}$ pools and several explanatory plant traits enabled for the first time to distinguish ten grain legume species according to their functional profiles. Hence, the characterization of grain legume species according to a combination of plant traits assesses their potential abilities to deliver $\mathrm{N}$ functions and support the resulting ecosystem services. Legumes with a high ability to take up soil $\mathrm{N}$ during their growth cycles and inducing low $\mathrm{N}$ losses by leaching after their harvest (chickpea, common bean, and soybean) were distinguished from species with a low ability to take up soil $\mathrm{N}$, thus posing higher risks of $\mathrm{N}$ leaching, but inducing high amounts of $\mathrm{N}$ in the following wheat (common vetch, faba bean, lentil, pea, and Narbonne vetch). In given situations, the establishment of these profiles should facilitate the selection of appropriate legume species according to the intended objectives and appropriately adjust $\mathrm{N}$ management in cropping systems that include grain legumes.

The profiles in this study were established in the Burgundy region of France. Characterizing the same legume species in different environments might require re-evaluating trait attributes or the integration of new traits that would be better adapted to the environmental constraints of the new situation. Ecosystem services relative to $\mathrm{N}$ are influenced by climatic conditions, which can affect $\mathrm{N}$ functions (i) directly, such as $\mathrm{N}$ leaching, or (ii) indirectly, by impacting plant traits and plant properties that determine the provision of $\mathrm{N}$ functions. However, the functional profiles were relatively well maintained between both experiments that were nonetheless characterized by contrasting climatic conditions.

Lastly, ecosystem services and dis-services are modulated by agricultural practices. For example, the establishment of cover crops during the fallow period, or the choice of a following crop with an earlier sowing date and with higher early stage $\mathrm{N}$ requirements than wheat (e.g., rapeseed oil), could substantially reduce $\mathrm{N}$ leaching losses after the legume harvest.

Acknowledgments We thank L. Andriot, F. Bizouard, M. Chanis, A. Coffin, M. Dourneau, V. Durey, S. Girodet, C. Jeudy, L. Lebeigle, M. Lefebvre, F. Lombard, P. Mathey, E. Pimet, B. Serbource, J. Walter for their excellent technical assistance, all the members of the Experimental Station in Bretenière for carrying out the field experiments, D. Moreau for her constructive comments on the work, G. Adeux for help with statistical analyses and R. Barnard for help with editing.

Authors' contribution "Conceptualization, A-S.V., and B.N.; investigation, A-S.V., B.N., and. M.G.; formal analysis, M.G.; visualization, M.G.; writing-review \& editing, M.G.; writing-original draft, M.G.; writing-review and editing, A-S.V., B.N., and. M.G.; funding acquisition, A-S.V., and B.N.

Funding information M. Guinet received a grant from the INRAE and the Ministry of Agriculture. This experimental work was supported by the ANR LEGITIMES (ANR-13-AGRO-0004), INRAE and Bourgogne Franche-Comté Region (PSDR project ProSys), the European Community under grant agreement no FP7-613551 (LEGATO project), and Terres Inovia.

\section{Compliance with ethical standards}

Conflict of interest The authors declare that they have no conflict of interest.

\section{References}

AFNOR (2018) Norme FD U44-163. Amendements organiques et supports de culture - Caractérisation de la matière organique par la minéralisation potentielle du carbone et de l'azote. AFNOR, La Plaine Saint Denis, France

Anglade J, Billen G, Garnier J (2015) Relationships for estimating N2 fixation in legumes: incidence for $\mathrm{N}$ balance of legume-based cropping systems in Europe. Ecosphere 6(3):1-24. https://doi.org/ 10.1890/ES14-00353.1

Bennett EM, Peterson GD, Gordo LJ (2009) Understanding relationships among multiple ecosystem services. Ecol Lett 12(12):1394-1404. https://doi.org/10.1111/j.1461-0248.2009.01387.x

Blesh J (2018) Functional traits in cover crop mixtures: biological nitrogen fixation and multifunctionality. J Appl Ecol 55(1):38-48. https://doi.org/10.1111/1365-2664.13011

Bourion V, Laguerre G, Depret G, Voisin A-S, Salon C, Duc G (2007) Genetic variability in nodulation and root growth affects nitrogen fixation and accumulation in pea. Ann Bot 100(3):589-598. https:// doi.org/10.1093/aob/mcm147

Brisson N, Gary C, Justes E, Roche R, Mary B, Ripoche D, Zimmer D, Sierra J, Bertuzzi P, Burger P (2003) An overview of the crop model STICS. Eur J Agron 18(3-4):309-332. https://doi.org/10.1016/ S1161-0301(02)00110-7

Byrnes JEK, Gamfeldt L, Isbell F, Lefcheck JS, Griffin JN, Hector A, Cardinale BJ, Hooper DU, Dee LE, Emmett Duffy J (2014) Investigating the relationship between biodiversity and ecosystem multifunctionality: challenges and solutions. Methods Ecol Evol 5(2):111-124. https://doi.org/10.1111/2041-210X.12143

Damour G, Dorel M, Quoc HT, Meynard C, Risède J-M (2014) A traitbased characterization of cover plants to assess their potential to provide a set of ecological services in banana cropping systems. Eur J Agron 52:218-228. https://doi.org/10.1016/j.eja.2013.09.004

Dunbabin V, Diggle A, Rengel Z (2003) Is there an optimal root architecture for nitrate capture in leaching environments? Plant Cell Environ 26(6):835-844. https://doi.org/10.1046/j.1365-3040.2003. 01015.x

Evans J, McNeill AM, Unkovich MJ, Fettell NA, Heenan DP (2001) Net nitrogen balances for cool-season grain legume crops and contributions to wheat nitrogen uptake: a review. Aust J Exp Agric 41:347359. https://doi.org/10.1071/EA00036 
Garnier E, Navas M-L (2012) A trait-based approach to comparative functional plant ecology: concepts, methods and applications for agroecology. A review. Agron Sustain Dev 32(2):365-399. https:// doi.org/10.1007/s13593-011-0036-y

Guinet M (2019) Quantification des flux d'azote induits par les cultures de légumineuses et étude de leurs déterminants : comparaison de 10 espèces de légumineuses à graines, Thèse de Doctorat de l'Université de Bourgogne Franche-Comté

Guinet M, Nicolardot B, Revellin C, Durey V, Carlsson G, Voisin A-S (2018) Comparative effect of inorganic $\mathrm{N}$ on plant growth and $\mathrm{N}_{2}$ fixation of ten legume crops: towards a better understanding of the differential response among species. Plant Soil 432(1-2):207-227. https://doi.org/10.1007/s11104-018-3788-1

Hauggaard-Nielsen H, Ambus P, Jensen ES (2001) Temporal and spatial distribution of roots and competition for nitrogen in pea-barley intercrops - a field study employing 32P technique. Plant Soil 236:6374. https://doi.org/10.1023/A:1011909414400

Isbell F, Calcagno V, Hector A, Connolly J, Harpole WS, Reich PB, Scherer-Lorenzen M, Schmid B, Tilman D, Van Ruijven J (2011) High plant diversity is needed to maintain ecosystem services. Nature 477(7363):199-202. https://doi.org/10.1038/nature10282

Jeudy C, Adrian M, Baussard C et al (2016) RhizoTubes as a new tool for high throughput imaging of plant root development and architecture: test, comparison with pot grown plants and validation. Plant Methods 12(1):31. https://doi.org/10.1186/s13007-016-0131-9

Kumar K, Goh KM (2003) Nitrogen release from crop residues and organic amendments as affected by biochemical composition. Commun Soil Sci Plant Anal 34(17-18):2441-2460. https://doi. org/10.1081/CSS-120024778

Lescourret F, Magda D, Richard G, Adam-Blondon AF, Bardy M, Baudry J, Doussan I, Dumont B, Lefèvre F, Litrico I (2015) A social-ecological approach to managing multiple agro-ecosystem services. Curr Opin Environ Sustain 14:68-75. https://doi.org/10. 1016/j.cosust.2015.04.001

Matlab (2015) MATLAB and statistical toolbox release 2015a. The MathWorks, Inc., Natick

MEA (2005) Millennium ecosystem assessment: ecosystem and human well-being: Synthesis. Island Press, Washigton

Palm CA, Gachengo CN, Delve RJ, Cadisch G, Giller KE (2001) Organic inputs for soil fertility management in tropical agroecosystems: application of an organic resource database. Agric Ecosyst Environ 83(1-2):27-42. https://doi.org/10.1016/S0167-8809(00)00267-X

Palmer J, Thorburn PJ, Biggs JS, Dominati EJ, Probert ME, Meier EA, Huth NI, Dodd M, Snow V, Larsen JR, Parton WJ (2017) Nitrogen cycling from increased soil organic carbon contributes both positively and negatively to ecosystem services in wheat agro-ecosystems. Front Plant Sci 8:731. https://doi.org/10.3389/fpls.2017.00731

Peoples MB, Hauggaard-Nielsen H, Huguenin-Elie O, Jensen ES, Justes E, Williams M (2019) The contributions of legumes to reducing the environmental risk of agricultural production. In: Agroecosystem
Diversity: Reconciling comtempory agriculture and environmental quality. Elsevier, Academic Press, pp 123-143. https://doi.org/10. 1016/B978-0-12-811050-8.00008-X

Plaza-Bonilla D, Nolot JM, Raffaillac D, Justes E (2015) Cover crops mitigate nitrate leaching in cropping systems including grain legumes: field evidence and model simulations. Agric Ecosyst Environ 212:1-12. https://doi.org/10.1016/j.agee.2015.06.014

Power AG (2010) Ecosystem services and agriculture: tradeoffs and synergies. Philos Trans R Soc B 365(1554):2959-2971. https://doi.org/ 10.1098/rstb.2010.0143

R Development Core Team (2016) R: a language and environment for statistical computing. Austria, Vienna

Rennie RJ, Rennie DA (1983) Techniques for quantifying N2 fixation in association with nonlegumes under field and greenhouse conditions. Can J Microbiol 29(8):1022-1035. https://doi.org/10.1139/m83160

Schiltz S, Munier-Jolain N, Jeudy C, Burstin J, Salon C (2005) Dynamics of exogenous nitrogen partitioning and nitrogen remobilization from vegetative organs in pea revealed by ${ }^{15} \mathrm{~N}$ in vivo labeling throughout seed filling. Plant Physiol 137(4):1463-1473. https://doi.org/10. 1104/pp.104.056713

Šmilaueur P, Lepš J (2014) Multivariate analysis of ecological data using CANOCO 5, 2nd end. Cambridge University Press, Cambridge. https://doi.org/10.1017/CBO9781139627061

Tibi A, Therond O (2017) Evaluation des services écosystémiques rendus par les écosystèmes agricoles. Une contribution au programme EFESE. Synthèse du rapport d'étude. Inra (France)

Tilman D, Cassman KG, Matson PA, Naylor R, Polasky S (2002) Agricultural sustainability and intensive production practices. Nature 418(6898):671-677. https://doi.org/10.1038/nature01014

Unkovich MJ, Pate JS (2000) An appraisal of recent field measurements of symbiotic $\mathrm{N}^{2}$ fixation by annual legumes. Field Crop Res 65: 211-228. https://doi.org/10.1016/S0378-4290(99)00088-X

Van Kessel C, Hartley C (2000) Agricultural management of grain legumes: has it led to an increase in nitrogen fixation? Field Crop. Res. 65:165-181. https://doi.org/10.1016/S0378-4290(99)00085-4

Van Soest PJ (1963) Use of detergents in the analysis of fibrous feeds. 2. A rapid method for the determination of fiber and lignin. J Ass off agric Chem 46:829-835

Violle C, Navas ML, Vile D, Kazakou E, Fortunel C, Hummel I, Garnier E (2007) Let the concept of trait be functional! Oikos 116(5):882 892. https://doi.org/10.1111/j.0030-1299.2007.15559.x

Voisin AS, Guéguen J, Huyghe C, Jeuffroy MH, Magrini MB, Meynard JM, Mougel C, Pellerin S, Pelzer E (2014) Legumes for feed, food, biomaterials and bioenergy in Europe: a review. Agron Sustain Dev 34:361-380. https://doi.org/10.1007/s13593-013-0189-y

Publisher's note Springer Nature remains neutral with regard to jurisdictional claims in published maps and institutional affiliations. 